\title{
DISEQUILIBRIUM IN HOUSING MODELS
}

\author{
RAY C. FAIR*
}

\section{INTRODUCTION}

The housing and mortgage markets have long been considered to be markets that may not always be in equilibrium, and many econometric models of the housing and mortgage markets have tried in one way or another to account for disequilibrium effects. In this paper a critique of previous models of the housing and mortgage markets is made. The main argument of the paper is that disequilibrium effects have not been accounted for in an adequate way in most models. A related argument of the paper is that many models have not captured in an adequate way the interaction between the housing and mortgage markets.

In Section II a general model of the housing and mortgage markets, based on the model in [5, Chapter 8], is outlined, and then in Section III previous models of the housing and mortgage markets are analyzed within the framework of the model outlined in Section II. Section IV concludes with suggestions for future research. It should be noted that while representative models were chosen for review in Section III, the list of models reviewed is by no means exhaustive. This paper is not meant to be a survey of the literature on housing and mortgage models, but is merely meant to be a critique of models with respect to the specification of disequilibrium effects and with respect to the specification of the interaction between the housing and mortgage markets. ${ }^{1}$ Also, the critical tone of the paper regarding these two issues should not be interpreted as a degradation of the significant progress that has been made in the past two decades in understanding the workings of the housing and mortgage markets.

\section{An Outline of a Model of the Housing and Mortgage Markets}

There are three basic groups of participants in the housing and mortgage markets: people who demand housing services and the funds to finance housing purchases, people who build new houses and remodel existing houses, and people who supply the funds to finance housing purchases.

The specification of the factors that influence the demand for housing services is fairly straightforward. The theory of consumer behavior indicates that the demand for a good or service should be a function of income and of the price of the good or service relative to all other prices. Per capita demand for housing services should thus be a function of per capita income and of the price of housing services relative to other prices. Demographic factors, such as the age

* Assistant Professor of Economics, Princeton University. I am indebted to Paul N. Courant for a survey of previous housing and mortgage models and for many helpful suggestions and comments throughout the course of this study.

1. See Grebler and Maisel [8] for a survey of the literature up to about 1960. The models discussed in this paper all postdate the Grebler and Maisel survey. See Fromm [7] for a tabulation of some of the more recent models. 
distribution of the population, should also have some effect on the per capita demand for housing services. For people who own their own home, the price of housing services depends not only on the price of the house, but also on the cost of borrowing the funds to finance the purchase of the house and on expenses for taxes and maintenance.

The specification of the factors that influence the supply of housing services is more complicated. Given the institutional framework in the United States, the supply of funds to finance housing purchases comes primarily from Savings and Loan Associations (SLAs) and Mutual Savings Banks (MSBs), with Life Insurance Companies and Commercial Banks playing a somewhat smaller role. Because of the various restrictions placed on SLAs and MSBs, mortgages and other kinds of long-term debt instruments are not likely to be perfect substitutes, and so the supply of mortgage funds should depend in part on the size of the deposits of SLAs and MSBs. The larger is the size of the deposits of SLAs and MSBs, other things being equal, the larger is the supply of mortgage funds likely to be. Since there is likely to be at least some substitution in the aggregate between mortgages and other long-term debt instruments, the supply of mortgage funds should also be a function of the mortgage rate relative to the rates on competing instruments.

The supply side of the housing market also includes the construction sector, and this sector is perhaps the most difficult to analyze. A builder's decision on whether to build a house (or set of houses) should depend, among other things, on the expected selling price of the house relative to the expected cost of building the house. For many builders, the decision may also depend on the expected profitability of residential construction relative to the expected profitability of non-residential construction. Most home builders finance the building of houses by short-term borrowings from Commercial Banks, and so part of the cost of building a house is the cost of short-term credit. Other costs include material and labor costs. What makes the construction sector difficult to analyze is the dependence of builders' decisions on expectations. The expected profitability of building a house is a function of the (subjective) probabilities of being able to sell the house at various prices, and it is difficult to determine empirically the factors that influence these probabilities. In the short run builders may overbuild in the sense that they end up having to sell houses at a loss.

If the housing and mortgage markets were always in equilibrium, the price of housing services would clear the housing market and the mortgage rate would clear the mortgage market. ${ }^{2}$ Equilibrium in the housing market would correspond to a positive number of vacancies, the number being the amount needed to meet the normal requirements of market turnover. In the short run the markets may not always be in equilibrium, however, and if disequilibrium does exist, an attempt has to be made to specify how the actual quantity of housing services and the actual quantity of mortgages get determined. One plausible

2. The expression "mortgage rate" is used here to refer to the total cost of mortgage credit. If various fees are charged when a mortgage is taken out, these fees are considered to be part of the mortgage rate. 
assumption to make when a market is not in equilibrium is that the observed quantity traded in the market is equal to the minimum of the quantity demanded and the quantity supplied. If the quantity demanded is greater than the quantity supplied, demanders are likely to go unsatisfied, and if the quantity supplied is greater than the quantity demanded, suppliers are likely to go unsatisfied. In the case of the housing and mortgage markets, however, the situation is somewhat more complicated than a simple analysis of supply and demand schedules would indicate because of the fixed supply of houses in the short run and because of the interaction between the two markets.

At any one time there is a certain number of houses either occupied or vacant and available for occupancy and a certain number of houses under construction. ${ }^{3}$ The supply of houses at any one time is thus fixed. If at the existing set of prices the quantity of houses demanded is equal to the available supply less the normal level of vacancies, then the housing market is in equilibrium; otherwise not. If the quantity demanded is greater than the available supply less the normal level of vacancies, then the actual level of vacancies will be less than normal and there may be people who would like to buy or rent houses at the available prices who cannot find any. This situation should over time cause prices to rise and builders to build more houses than they otherwise would to meet the normal growth of housing needs caused by removals and population growth. If the quantity demanded is smaller than the available supply less the normal level of vacancies, then the actual level of vacancies will be greater than normal and there may be people who would like to sell their houses at the available prices who cannot find anyone to buy them. This situation should over time cause prices to fall and builders to build fewer houses than they otherwise would. How quickly the housing market moves toward equilibrium will depend, among other things, on how quickly builders respond to disequilibrium situations. As mentioned above, builders may in fact overrespond in the short run and build houses that they end up having to sell at a loss.

Consideration must now be given to how the financial sector affects the housing market. Since the cost of mortgage credit (the mortgage rate) is part of the price of housing services, the mortgage rate is one of the factors that influence the demand for housing services. In addition, as mentioned above, the cost of short-term credit is one of the factors that influence the supply of housing services. If the housing and financial markets are not always in equilibrium, then the financial markets may also have an effect on the housing market other than through the effects of the mortgage rate and the short-term rate. During periods of tight money when the deposits of SLAs and MSBs and perhaps other financial intermediaries are decreasing or increasing less than normal, the mortgage rate may not rise enough to clear the mortgage market. In this case, new mortgage credit must be rationed, which means that the mortgage market will not be in equilibrium. In the present institutional framework in the United States, the rationing effect from the mortgage market to the housing

3. In the following analysis the quantity of housing services will be assumed to be proportional to the number of houses. The word "house" is meant to refer to apartments as well as single-family houses. 
market is likely to show up in large part in the form of financial intermediaries not granting as many mortgage commitments to builders as the builders would like. Home builders generally need a mortgage commitment from a financial intermediary before they can get short-term loans from Commercial Banks, and if mortgages are being rationed, the desired number of commitments from the point of view of the builders will not be forthcoming. It should be noted in passing that home builders are not generally concerned with the cost of mortgage credit, only with the availability of mortgage credit. The credit costs to the builder are short-term costs. The cost of mortgage credit will affect builders only to the extent that the cost affects their subjective probabilities of being able to sell their houses at profitable prices.

The rationing effect from the mortgage market to the housing market may also show up in the form of financial intermediaries increasing down payment requirements and the like. If at the existing mortgage rate an individual wants to borrow, say, 80 percent of the value of his proposed new home and the financial intermediary will only loan him 70 percent, this can be considered to be a form of credit rationing. Risk considerations will probably prohibit financial intermediaries from loaning to individuals 100 percent of the value of their homes, but to the extent that financial intermediaries change the percent that they will loan according to market conditions, this is a form of credit rationing. Credit would not be rationed if financial intermediaries kept down payment requirements constant and let the mortgage rate rise to the point where the amount demanded was equal to the amount they had available to supply.

Rationing in the mortgage market will thus have a negative effect on the number of new houses built. The number of new houses built will be limited to the number of new houses the mortgage market is willing to finance. This restriction will show up in the form of builders not being able to get as many mortgage commitments as they would like at the existing set of prices and individuals who build their own homes not being able to take out as many mortgages as they would like at the existing set of prices. In this case the housing market is in disequilibrium in the sense that were it not for mortgage rationing, builders would like to build more houses at the existing set of prices than they are in fact building. Given the restricted supply of houses, the price of houses is, of course, likely to rise, and it is conceivable (although perhaps not very likely) that the price of houses would rise far enough to choke off enough demand to equate the quantity demanded to the restricted supply. If the price of houses does not rise this far, then some demanders will go unsatisfied at the existing set of prices.

It is important to note that disequilibrium in the mortgage market has an asymmetrical effect on the housing market. If the mortgage rate is too high in the sense that the supply of mortgages is greater than the demand, this should have little effect on the housing market. Builders (including people who build their own homes) will be able to get all of the mortgage commitments that they want, and the fact that financial intermediaries would like to issue more commitments than the builders are taking should not in general induce the builders to take any more. There may be some cases in which excess supply in the 
mortgage market has caused builders to build more houses than they otherwise would (given their expectations and the existing set of prices and costs), but it does not seem likely that this will happen very often. Only if excess supply in the mortgage market causes builders to change their expectations about selling prices would excess supply in the mortgage market be expected to have a significant effect on the housing market, and it does not seem very likely that excess supply in the mortgage market would have a significant effect on builders' selling-price expectations. With respect to the demand for houses, one would also not expect that excess supply in the mortgage market would have a significant effect on the demand for houses. The cost of mortgage credit should certainly affect demand since it is part of the price of housing services, but the mere fact that financial intermediaries would like to issue more mortgages at the current mortgage rate than they are issuing should not affect demand directly. Only to the extent that excess supply in the mortgage market causes the cost of mortgage credit to fall in the future should the demand for housing services be affected.

In summary, then, the mortgage market will have a constraining effect on housing activity if there is excess demand in the mortgage market and rationing occurs, but otherwise the mortgage market affects housing activity only through the effect of the mortgage rate on the demand for houses. Disequilibrium in the housing market occurs when the price of housing services does not adjust fast enough to clear the market. The housing market can be shocked out of equilibrium either by builders misreading the market and underbuilding or overbuilding or by builders being prevented from building the equilibrium number of houses by not being able to get all of the mortgage commitments from the financial intermediaries that they would like at the existing set of prices.

This completes the outline of the model that will be used as a basis for the critique in Section III. It should be emphasized that the model is highly generalized and has left out many details. In particular, little attention has been given to specifying the factors that actually determine builders' expectations, and no attention has been given to questions of disaggregation. Also, no distinction has been made between the number of houses and the value of houses. It is interesting to note, however, that the model does provide the mechanism by which both mortgage credit and builders' expectations can have significant effects on housing starts. Guttentag [9] and Alberts [1] were two of the first to emphasize the role of mortgage credit, and Maisel [14] was one of the first to emphasize the role of builders' expectations.

Before presenting the discussion of previous models in Section III, a brief discussion of the housing starts model in [5] will be given. The model in [5] is consistent with the above theoretical framework, but a number of simplifying assumptions were made in specifying the model. First, the assumption was made that builders build either the quantity of new houses demanded or the quantity of new houses that the mortgage market is willing to finance, whichever is smaller. Two equations were then estimated-an equation explaining the demand for housing starts and an equation explaining the number of housing starts that the mortgage market is willing to finance. The latter equa- 
tion is in effect a supply equation of housing starts from the mortgage market. Since the observed number of housing starts was not necessarily assumed to be equal to both the number demanded and the number supplied, the supply and demand equations could not be estimated by standard econometric techniques. The equations were instead estimated by one of the four techniques developed in Fair and Jaffee [6] for estimating supply and demand schedules in disequilibrium markets. Three of the four techniques developed in [6] were designed to separate the sample period into demand and supply regimes so that each schedule could be fitted against the observed quantity for the sample points falling within its regime. The fourth technique was designed to adjust the observed quantity for the effects of rationing so that both schedules could be estimated over the entire sample period using the adjusted quantity. The fourth technique provides a test of the hypothesis that rationing has eccurred in the particular market in question. The fourth technique was the one used in [5], and the results indicated that rationing has occurred in the housing and mortgage markets.

The model in [5] was designed for forecasting purposes and was kept relatively simple. The model is concerned only with the market for new houses (starts), and it assumes that the construction sector plays only a passive role in determining the number of starts. The model is not put forth as a complete specification of the housing and mortgage markets, but only as a first step in trying to take into account the disequilibrium aspects of the markets and the relationship between the two markets.

\section{A Critrque of Previous Models}

\section{The Muth Model}

Muth [16] is primarily concerned with the demand for housing. The desired per capita stock of housing is a function of income and price. Two price variables are included in the equation explaining the desired per capita stock of housing: the price of houses and the mortgage rate. Muth argues that in the long run the supply of housing from the construction sector is highly elastic (p. 46), but in the short run he specifies a lagged adjustment process of actual housing stock toward desired stock. The lack of instantaneous adjustment may be due to both demand and supply effects (pp. 35-36).

Muth's model has allowed for disequilibrium effects in the housing market by postulating the lagged adjustment process. At any point in time the actual stock of housing is groping its way toward the desired or equilibrium stock. The lagged-adjustment process does not, however, capture the restrictive effect that the mortgage market can have on the housing market. If credit rationing occurs, the actual stock of housing may be prevented from adjusting toward the desired stock by as much as the lagged-adjustment process indicates it should. Adjustment toward the desired stock is always at the same rate in Muth's model, and this does not appear to be a reasonable assumption to make for the housing market in view of the effect that the mortgage market can have on the housing market. Much of the time adjustment may not be restricted at all, but some of the time adjustment may be restricted quite severely. 
Maisel's model [14] is based on the definition that the level of housing starts (St) equals net household formation $(\Delta \mathrm{HH})$ plus net removals (Rem) plus changes in vacancies about their trend $(\Delta V)$ plus changes in inventories under construction $(\Delta \mathrm{I}):^{4}$

$$
\mathrm{St}=\Delta \mathrm{HH}+\mathrm{Rem}+\Delta \mathrm{V}+\Delta \mathrm{I} .
$$

In his theoretical model Maisel specifies the factors that explain each of the four components of housing starts, but in his empirical work he estimates only one "reduced form" equation explaining housing starts. The equation is, however, not really a reduced form equation since two of the components of housing starts, net household formation and net removals, are included directly as explanatory variables in the equation. In order for the equation that Maisel estimated to be a reduced form equation, the coefficients on the net-householdformation variable and the net-removal variable would have to be constrained to be one or else the determinants of these two variables would have to be used in the equation in place of the variables themselves. ${ }^{5}$

More seriously perhaps, Maisel has not treated inventories under construction properly. The change in inventories under construction is by definition equal to starts minus completions. Assume without loss of generality that completions in the current quarter are equal to starts of two quarters ago. ${ }^{6}$ The change in inventories under construction is then by definition equal to starts of the current quarter minus starts two quarters ago $(\Delta \mathrm{I}=\mathrm{St}-\mathrm{St}-2)$. Maisel's definition (1) is thus

$$
\mathrm{St}=\Delta \mathrm{HH}+\operatorname{Rem}+\Delta \mathrm{V}+\mathrm{St}-\mathrm{St}_{-2},
$$

or

$$
S t_{-2}=\Delta \mathrm{HH}+\mathrm{Rem}+\Delta \mathrm{V} \text {. }
$$

Since $\mathrm{St}_{-2}$ is completions in the current quarter, equation $(2)^{\prime}$ correctly states that the level of completions is by definition equal to net household formation plus net removals plus the change in vacancies. What the above analysis suggests, then, is that there should not be an error term in Maisel's equation explaining the change in inventories under construction and that Maisel should have worked with definition $(2)^{\prime}$. What Maisel did in fact do was to take the current change in inventories $(\Delta \mathrm{I})$ to be a function of housing starts lagged one and three quarters respectively and to put these latter two variables in the equation explaining current housing starts (St). This procedure introduces two

4. For purposes of the definition, $\Delta V$ should actually be just the change in vacancies rather than the change in vacancies about their trend. Maisel deals only with the change in vacancies about their trend and proceeds to write the definition as in (1), which is not, strictly speaking, correct.

5. Essentially this point was made by Warren Smith in the discussion that followed Maisel's presentation at the Conference on Savings and Residential Financing, Chicago, May 1965. See [15], pp. $145-146$.

6. Maisel assumes that completions in the current month are equal to starts six months earlier (p. 370). The following analysis remains unchanged if completions in the current quarter are made some weighted average of starts of one and two quarters ago. All this would do would be to change the left-hand-side variable in equation $(2)^{\prime}$ to the particular weighted average used. 
lagged dependent variables into the equation and converts the equation into a difference equation, but the procedure makes no sense within the context of Maisel's theoretical framework.

Despite the above criticisms, it is still possible to put much of Maisel's theoretical discussion within the framework outlined in Section II. Maisel believes that demand is fairly stable and assigns "a low importance to household formation and net removals as a cause of postwar housing fluctuations" (p. 374). Much of his discussion emphasizes the construction sector and in particular the importance of builders' expectations in determining short-run movements in housing starts (pp. 366-370). The mortgage market does not play a central role in Maisel's analysis, although credit costs are postulated as having an important effect on builders' decisions (p. 378). Credit costs have little, if any, effect on the demand for housing starts, although credit costs may affect the value demanded per start. ${ }^{7}$ Maisel also states that the availability of credit may be important as well as its cost (pp. 369, 378), but this line of argument is not pursued beyond using a short-term rate rather than a longterm rate in the equation explaining housing starts. The explanatory variables in the housing starts equation, aside from the short-term rate, the two lagged dependent variables, the net-household-formation variable, and the net-removal variable, are the deviation of vacancies at the beginning of the quarter from trend and the ratio of rents to construction costs lagged one quarter. The equation does not allow for the effect of credit rationing except through the effect of the short-term rate, and even if the short-term rate can be taken as a proxy for credit rationing, the mere inclusion of the short-term rate as an explanatory variable in the equation does not allow for the asymmetrical effect of credit rationing.

\section{The Sparks Model}

Sparks' model [18] is an attempt "to combine Maisel's approach with a more detailed treatment of the supply of mortgage funds" (p. 304). In the model the change in housing starts is taken to be a function of the change in the level of vacancies plus inventories under construction of the previous period, of the change in the ratio of rents to construction costs of the previous period, of the change in mortgage credit terms, of the change in net household formation, and of the change in disposable income. Sparks also specifies supply and demand equations for mortgage commitments. The change in the demand for mortgage commitments is a function of the same variables that determine the change in housing starts. The change in the supply of mortgage commitments from each financial intermediary is a function of the change in the inflow of savings deposits of the intermediary, of the change in mortgage repayments of the intermediary, of the change in the ratio of the intermediary's mortgage holdings to its deposits of the previous period, of the change in mortgage credit terms, and of the change in a representative yield on competing assets.

Sparks equates supply and demand in the mortgage market and thus assumes

7. See Maisel [15], pp. 132-135, for a clear discussion of this. 
that the mortgage market is always in equilibrium. The mortgage market affects housing starts through the cost of mortgage credit. ${ }^{8}$ Two basic criticisms can be made regarding Sparks' housing starts equation. The first is that the equation is neither a supply equation nor a demand equation nor a reduced form equation. There are two price variables in the equation (the cost of mortgage credit and the ratio of rents to construction costs), two other determinants of demand (household formation and income), and one other determinant of supply (vacancies plus inventories under construction). Sparks did not specify separate supply and demand equations for the housing market, as he did for the mortgage market, and the housing starts equation that he ended up with does not appear to have much theoretical justification. The other basic criticism regarding Sparks' model is that by assuming equilibrium in the mortgage market, he has not allowed the mortgage market to affect the housing market other than through the cost of credit.

\section{The Smith Model}

In Smith's model [17] the level of housing starts is a function of the price of houses, of the vacancy rate, of construction and land costs, and of the cost and availability of mortgage credit. With respect to the availability of mortgage credit, the yield differential between mortgages and bonds was used as an explanatory variable in the housing starts equation to represent "private creditrationing effects" (p. 799). A public credit-availability variable was also included in the housing starts equation. Aside from the credit-availability variables, Smith's housing starts equation can be considered to be a supply equation of housing starts from the construction sector. The equation can be criticized for failing to take into account the asymmetrical effect of credit rationing. The credit-availability variables should not merely be included in the equation as explanatory variables. Also, given that Smith's equation is a supply equation from the construction sector, the credit-cost variable should probably be a variable measuring short-term costs rather than mortgage costs.

Smith also specifies supply and demand equations for housing stock and for mortgages. He equates supply and demand in each market and solves respectively for the price of housing and the mortgage rate. He then estimates the resulting equations explaining the price of housing and the mortgage rate. $\mathrm{He}$ also estimates an equation explaining the stock of houses (as a function of lagged stock and current and lagged housing starts) and equations explaining mortgage approvals from three financial intermediaries. By equating supply and demand in the mortgage market, Smith assumes that the market is always in equilibrium, and this assumption is inconsistent with the use of creditrationing variables in the housing starts equation. Smith also tried (again incorrectly) $w$ introduce credit-rationing variables in the equations explaining the price of housing and the stock of houses, but the variables were not significant (p. 802).

8. Sparks actually estimates his housing starts equation by substituting the determinants of the mortgage credit variable for the variable itself, but it is not necessary to consider this procedure here. 


\section{The Brady Model}

Brady [2] disaggregates housing investment by type of mortgage used to finance the investment-conventional, FHA, or VA. He takes a highly empirical approach and chooses as explanatory variables in the housing investment equations those variables that led to the best fits. Included as explanatory variables in the equation explaining conventionally-financed housing investment are an index of monetary stringency, the mortgage rate, the spread between the mortgage rate and the bond rate, and the length of the amortization period. This equation can be interpreted as a supply equation from the financial sector. Included as explanatory variables in the equation explaining FHA-financed housing investment are the ratio of rents to consumer prices, the spread between the mortgage rate and the bond rate, the loan-to-value ratio, mortgage commitments by Life Insurance Companies lagged two quarters, and acquisitions of mortgages by FNMA. This equation could also be interpreted as a supply equation from the financial sector were it not for the inclusion of the ratio of rents to consumer prices, which is a variable relevant for the demand equation and perhaps for the supply equation from the construction sector, but not for the supply equation from the financial sector. The equation explaining VA-financed housing investment is similar to the equation explaining FHAfinanced housing investment except without the ratio of rents to consumer prices included as an explanatory variable, and so the equation can also be interpreted as a supply equation from the financial sector.

If Brady's equations are interpreted as supply equations from the financial sector, then the implicit assumption in the model is that supply from the construction sector and demand are always sufficient to absorb the supply from the financial sector. The markets can never be in disequilibrium in the sense of the quantity supplied from the financial sector being greater than the quantity demanded or the quantity supplied from the construction sector. The index of monetary stringency and the loan to value ratio can be interpreted as credit rationing variables, and again the mere use of these variables as explanatory variables does not take into account the asymmetrical effect of credit rationing.

\section{The Evans Model}

In the Evans model [4] investment in housing is a function of income, of the ratio of a cost index of residential construction to a rent index lagged three quarters, and of the spread between the long-term bond rate and the short-term commercial paper rate lagged three quarters (pp. 197-198). The latter variable is taken as a measure of credit market tightness (p. 191). In his discussion, Evans emphasizes the counter-cyclical nature of housing investment and argues that builders in some sense receive both residual credit and residual construction labor. He also states that "the function explaining residential construction is really more of a supply function than a demand function for short-run fluctuations" (p. 200). Evans' equation is, however, neither a supply equation nor a demand equation nor a reduced form equation. The income variable is a demand variable, the ratio of costs to rents is a price variable belonging pre- 
sumably in both demand and supply equations, and the interest-spread variable is a price variable and perhaps also a variable measuring credit-rationing effects. Evans' equation, by combining elements from the demand sector, from the construction sector, and from the financial sector, ends up not being able to be interpreted as a structural equation from any sector nor as a general reduced form equation. If the interest-spread variable is interpreted as a measure of credit rationing, then again the mere use of this variable as an explanatory variable does not take into account the asymmetrical effect of credit rationing.

\section{The DHL-III Model}

In the DHL-III model [11] the level of housing starts is a function of the level of starts lagged one and two quarters, of the two-quarter change in income lagged one quarter, and of a credit variable which is a step-function related to the spread between long and short interest rates (p. 28). Aside from the lagged dependent variables, the equation can be considered to be a demand equation if the credit variable is interpreted as a price variable. If the credit variable is interpreted as a credit-rationing variable, then the equation is subject to the criticism that the mere inclusion of the variable in the equation does not properly capture the asymmetrical effect of credit rationing. If the equation is interpreted as a demand equation, then the implicit assumption in the model is that supply from the construction sector and supply from the financial sector are always sufficient to meet the demand.

\section{The SSRC-MIT-PENN Model}

In the SSRC-MIT-PENN (SMP) model $[13]^{9}$ the per capita demand for the stock of houses is a function of per capita permanent income and of the implicit rental price for the stock of houses relative to general consumer prices. Since "in equilibrium, market clearing for homeowners requires that the cost of capital be equal to the ratio of the implicit rental price to the equilibrium price of the housing stock" (p. 26), the implicit rental price was set equal to the cost of capital times the price of the housing stock. The supply of real per capita housing starts is a function of the ratio of the price of the housing stock to housing construction costs. The demand equation was used to solve for the rental price, and the equilibrium assumption was then used to replace the rental price by the cost of capital times the price of the housing stock. This latter equation was then solved for the price of the housing stock (by dividing through by the cost of capital), and the resulting expression for the price of the housing stock was substituted into the supply equation. The real per capita value of housing starts thus became a function of the ratio of consumer prices to the cost of capital times the cost of construction, of the per capita stock of houses, and of per capita income.

The basic SMP housing model is thus an equilibrium model. The mortgage market affects housing activity through the cost variables. Credit rationing,

9. The housing model described in Kalchbrenner [13] is slightly changed from the housing model described in de Leeuw and Gramlich [3], and so attention will be concentrated on the more recent model in Kalchbrenner [13]. 
however, plays an important role in the overall SMP model, and credit rationing is also introduced in the housing starts equation..$^{10}$ The change in outstanding mortgage commitments of SLAs was added as an explanatory variable to the equation, along with the change in the flow of FNMA mortgage-holdings and the change in the financial component of household net worth. Also, "all three of these variables were estimated with lags to reflect the slow adjustment to equilibrium anticipated in the housing sector" (p. 37).

The main problem with the SMP housing model is that credit-rationing variables are tacked on at the end of the basic model and are not consistent with the equilibrium framework of the basic model. Even if the procedure were consistent, ${ }^{11}$ however, the model is subject to the criticism that it does not incorporate the asymmetrical effect of credit rationing.

\section{The Huang Model}

In the Huang housing model $[10],{ }^{12}$ the value of new houses bought (demand) is a function of the value lagged one quarter, of the change in the expected ratio of rents to housing prices, of the change in the mortgage rate, of the change in the average loan to value ratio, and of the change in the average length of amortization. The number of new houses started (supply) is a function of the number started one and two quarters ago, of the expected ratio of housing prices to construction costs, of a short-term interest rate, of vacancies (excess supply), and of the free reserves position of the Federal Reserve member banks. The latter variable is taken as a measure of general credit availability.

By distinguishing between houses bought and houses started, Huang allows for disequilibrium in the housing market. The mortgage market affects demand through the mortgage rate, the loan to value ratio, and the amortization variable. The mortgage market affects starts by affecting demand, which affects the level of vacancies. The non-mortgage financial sector affects starts through the short-term interest rate and the free-reserves variable. Again, the mere use of the free-reserves variable as an explanatory variable in the starts equation does not allow for the asymmetrical effect of credit rationing. Also, if the loan to value ratio is interpreted as a credit rationing variable, the mere use of this variable as an explanatory variable in the demand equation does not allow for the asymmetrical effect of credit rationing. Huang's housing model has thus accounted for disequilibrium in the housing market, but it has not accounted in an adequate way for the effect of disequilibrium in the mortgage market on the housing market.

In the Huang mortgage model $[9 \mathrm{a}]^{13}$ the demand for mortgages is a function

10. The following discussion relates to what was done in the single-family housing starts equation. A similar procedure was followed for the multi-family equation, but this will not be discussed here.

11. The procedure might be made consistent by assuming that the price of houses always adjusts to equate supply and demand in the housing market regardless of how much supply is restricted by credit rationing. (See the relevant discussion in Section II.) This does not, however, appear to be what the designers of the SMP housing model had in mind.

12. Huang presents equations for both single-family units and multi-family units, but attention will be concentrated here only on the equations for single-family units.

13. Huang also discusses the mortgage market in [10], but the discussion in [9a] is more complete and so will be considered here. 
of the mortgage rate, of the average maturity of mortgage loans, of income, of the desired level of the owner-occupied housing stock, and of the lagged stock of mortgages. The desired housing stock is taken to be a function of income and of the ratio of rents to housing prices. The lagged stock of mortgages enters because of an assumed lagged-adjustment process. The supply of mortgages is a function of the mortgage rate, of the corporate bond rate lagged one quarter, of the level of free reserves at Commercial Banks lagged two quarters, and of the net increase in earnings at banks and nonbank financial intermediaries. The mortgage rate is assumed to have a negative effect on demand and a positive effect on supply.

If the mortgage market is in equilibrium, then the observed quantity is equal to both the quantity demanded and the quantity supplied. Huang estimates his demand and supply equations using the observed quantity as a measure of the quantity demanded and the quantity supplied. He finds, as expected, that the mortgage rate has a negative effect on demand and a positive effect on supply. Huang's estimates of the supply and demand equations are thus based on the assumption that the mortgage market is in equilibrium. He then goes on, however, to assume disequilibrium in the mortgage market and to estimate an equation explaining the mortgage rate. He essentially assumes that the observed quantity is equal to the quantity demanded but not to the quantity supplied. His estimate of the mortgage rate equation is thus inconsistent with the assumptions made in estimating the supply and demand equations.

\section{The Jaffee Model}

Jaffee [12] is concerned only with the mortgage market and so his model will only be briefly discussed here. Jaffee specifies supply and demand equations for mortgages. Supply is disaggregated by financial intermediary. Both supply and demand are a function of the mortgage rate. Jaffee estimates his supply equations using the actual quantity of mortgages as the dependent variable, and so he assumes that the observed quantity is always equal to the supply. Instead of estimating his demand equation directly, however, Jaffee estimates an equation explaining the mortgage rate, where the mortgage rate is a function of the observed quantity of mortgages, of the variables in the demand equation (other than the mortgage rate itself), and of the mortgage rate lagged one quarter. Jaffee points out that this procedure is equivalent to one of the procedures developed in Fair and Jaffee [6] for estimating disequilibrium markets as long as the observed quantity is always equal to the quantity supplied, or equivalently in this context as long as the change in the mortgage rate is always nonnegative. This assumption was true for much of Jaffee's sample period, but in general the assumption will not be able to be used.

\section{CONCLUSTON}

The main conclusion of this paper is that most housing and mortgage models have not accounted in an adequate way for disequilibrium effects nor for the effects of the mortgage market on the housing market. Some models are inconsistent in their treatment of disequilibrium effects, and none of the models have accounted for the asymmetrical effect that disequilibrium in the mortgage market has on the housing market. Some models are also not clear on whether 
a demand equation is being estimated, a supply equation from the construction sector, a supply equation from the financial sector, or some sort of reduced form equation. In some cases the resulting equation cannot be interpreted as any one of these. Nevertheless, rapid progress has been made in the last decade in understanding the housing and mortgage markets, and the primary suggestion of this paper is that in the future more attention be given to disequilibrium effects and to the way in which the mortgage market affects the housing market. Much work is also needed in disaggregating the housing and mortgage markets by type of mortgage, by type of dwelling unit, and by region. Also, the federal government is playing more and more of a role in the two markets, and attention should be given as to what effect the various government activities are actually having.

Because of the rather complicated nature of the housing and mortgage markets, it is not particularly easy to specify the markets econometrically. Asymmetrical effects are difficult to specify econometrically, and the existence of disequilibrium in a market means that the observed quantity cannot be used both as a measure of the quantity demanded and as a measure of the quantity supplied. Clearly, more work is also needed in trying to develop econometric tools to handle disequilibrium problems.

\section{REFERENCES}

1. W. W. Alberts. "Business Cycles, Residential Construction Cycles, and the Mortgage Market," The Journal of Political Economy LXX (June, 1962), 263-281.

2. Eugene A. Brady. "A Sectoral Econometric Study of the Postwar Residential-Housing Market," The Journal of Political Economy LXXV (April, 1967), 147-158.

3. Frank de Leeuw and Edward M. Gramlich. "The Channels of Monetary Policy," Federal Reserve Bulletin LV (June, 1969), 472-491.

4. Michael K. Evans. Macroeconomic Activity. New York: Harper \& Row, 1969.

5. Ray C. Fair. A Short-Run Forecasting Model of the United States Econtomy. Lexington, Massachusetts: D. C. Heath and Company, 1971.

6. Ray C. Fair and Dwight M. Jaffee. "Methods of Estimation for Markets in Disequilibrium," Econometrica, forthcoming 1972.

7. Gary Fromm. "Econometric Models of the Residential Construction Sector: A Comparison," paper presented to the Housing Model Conference, Federal Home Loan Bank Board, March 5, 1971.

8. Leo Grebler and Sherman J. Maisel. "Determinants of Residential Construction: A Review of Present Knowledge," in Commission on Money and Credit, Impacts of Monetary Policy (Englewood Cliffs, N.J.: Prentice-Hall, 1963), 475-602.

9. Jack M. Guttentag. "The Short Cycle in Residential Construction, 1946-59," The American Economic Review LI (June, 1961), 275-298.

9a. David S. Huang, "The Short-term FIows of Nonfarm Residential Mortgages," Econometrica XXXIV (April 1966), 433-459.

10. David S. Huang. "A Study of the Market for New Housing Units," Proceedings of the Business and Economic Statistics Section of the American Statistical Association, 1969, 702-712.

11. Saul H. Hymans and Harold T. Shapiro. The DHL-III Quarterly Econometric Model of the U.S. Economy. Michigan: Research Seminar in Quantitative Economics, University of Michigan, 1970.

12. Dwight M. Jaffee. "An Econometric Model of the Mortgage Market: Estimation and Similation," in E. Gramlich and D. Jaffec, eds., Savings Deposits, Mortgages, and Residential Construction, forthcoming.

13. John H. Kalchbrenner. "Summary of the Current Financial Intermediary, Mortgage, and Housing Sectors of the SSRC-MIT-PENN Econometric Model," paper presented to the Housing Model Conference, Federal Home Loan Bank Board, March 5, 1971.

14. Sherman J. Maisel. "A Theory of Fluctuations in Residential Construction Starts," The American Economic Review LIII (June, 1963), 359-379. 
15. Sherman J. Maisel. "The Relationship of Residential Financing and Expenditures on Residential Construction," in Marshall D K.etchum and Norman Strunk, eds., Conference on Savings and Residential Financing, 1965 Proceedings, The United States Savings and Loan League.

16. Richard E. Muth. "The Demand for Non-Farm Housing," in Arnold C. Harberger, ed., The Demand for Durable Goods (Chicago: The University of Chicago Press, 1960), 29-96.

17. Lawrence B. Smith. "A Model of the Canadian Housing and Mortgage Markets," The Journal of Political Economy LXXVII (September/October, 1969), 795-816.

18. Gordon Sparks. "An Econometric Analysis of the Role of Financial Intermediaries in Postwar Residential Building Cycles," in Robert Ferber, ed., Determinants of Investment Behavior (New York: National Bureau of Economic Research, 1967), 301-331. 